\title{
Does enzyme heterozygosity influence developmental rate in rainbow trout?
}

\author{
Roy G. Danzmann, Moira M. Ferguson \\ and Fred W. Allendorf
}

\begin{abstract}
Department of Zoology, University of Montana, Missoula, Montana 59812.
\end{abstract}

The association between genetic variation at 14 enzyme loci and developmental rate was examined in six strains of rainbow trout (Salmo gairdneri). The purpose of this study was to test the prediction that heterozygotes develop faster than homozygotes. We also tested whether the enzyme loci could be responsible for such an association or are marking chromosomal segments that influence developmental rate. There is a significant negative association $(P<0 \cdot 05)$ between hatching time and the number of heterozygous loci per fish in one of six strains. Heterozygotes developed faster than homozygotes at $\mathbf{2 6}$ out of $\mathbf{4 3}$ possible comparisons made at individual loci within strains. Heterozygotes developed significantly faster than homozygotes in eight comparisons, and significantly slower in six comparisons. These results suggest a weak positive association between developmental rate and heterozygosity. Nine loci were polymorphic in more than one strain. At five of these loci the hatching distributions of heterozygotes and homozygotes are significantly different among strains. The direction of the relationship between heterozygosity and developmental rate at individual loci is not consistent among strains. Therefore, our results suggest that the loci surveyed are marking chromosomal segments that influence developmental rate. Linkage disequilibrium between alleles at the isozyme loci and dominantacting genes that accelerate or retard developmental rate is hypothesised to account for the observed relationship between heterozygosity and developmental rate.

\section{INTRODUCTION}

Several studies with fishes suggest that the enzyme products of genes may influence developmental rate through their effects on metabolic rate and flux. Since the products of such genes are part of major biochemical pathways, these enzymes may influence the timing of developmental events indirectly, by altering the rate of energy yielding reactions. DiMichele and Powers (1982; 1984) have reported differences in hatching time and metabolic rate between embryos of Fundulus heteroclitus with different lactate dehydrogenase phenotypes. Similarly, Allendorf et al. (1983) have shown that rainbow trout (Salmo gairdneri) with phosphoglucomutase (PGM1) activity in liver, resulting from allelic variation at a regulatory gene, develop faster than their full-sibs without liver PGM1.

Empirical and theoretical studies suggest that heterozygosity may have important influences on the developmental process. Leary et al. (1983; 1984) have reported an association between asymmetry of bilateral meristic characters and enzyme heterozygosity in several species of salmonid fishes. More heterozygous fishes were the most symmetrical and thus were the most developmentally stable, as predicted by Lerner's (1954) model of developmental homeostasis. We have hypothesised that differences in fluctuating asymmetry between homozygotes and heterozygotes may be the result of differences in developmental rate (Danzmann et al., 1986). We suggested that faster developmental rates would decrease the probability of accidents during critical periods of development resulting in lower fluctuating asymmetry of meristic characters. We observed in one strain of rainbow trout that heterozygotes tended to develop faster than homozygotes, suggesting that differences in developmental rate may account for the positive association between developmental stability and heterozygosity in rainbow trout.

The faster developmental rates of heterozygotes may be the result of the biochemical properties of the enzymes produced by different genes, or the enzyme loci may be marking chromosomal segments that influence developmental rate. To distinguish between these two alternative 
hypotheses we have examined the asscciation between (1) heterozygosity and hatching time in six strains of rainbow trout, and (2) specific alleles at individual loci and developmental time. The enzymes investigated in this study include glycolytic and citric acid cycle enzymes that are important energy yielding enzymes during early rainbow trout embryogenesis (Boulekbache, 1981). A consistent association between genotypes at any locus and developmental rate in several strains would suggest that the enzyme products of this locus directly influence developmental rate. Alternatively, if certain loci show strong positive associations between developmental rate and heterozygosity in some strains, but negative associations in other strains, then it is likely that such loci are marking chromosomal segments that carry other genes that affect developmental rate.

\section{MATERIALS AND METHODS}

\section{Experimental matings}

We used five strains of rainbow trout maintained by either the U.S. Fish and Wildlife Service or the Montana Department of Fish, Wildlife, and Parks. Table 1 gives the source of each strain, the dates of the experimental matings, and the number of males and females used. We have also included data from our previous study of the Arlee strain (Danzmann et al., 1986) for direct comparison to the results of the present study.

For each strain, gametes were removed from an equal number of males and females (table 1) at the spawning site, and transported to the University of Montana in styrofoam coolers packed with ice. Approximately equal numbers of eggs from several females were combined with equal volumes of sperm from several males to make a pooled pure strain cross. The embryos were incubated in darkness in Heath incubating racks at $7 \cdot 5^{\circ} \mathrm{C} \pm 1^{\circ} \mathrm{C}$.

\section{Origin of the strains}

Arlee The Arlee strain originated from at least two hatchery stocks, but has been randomly mating for at least 13 generations ( 32 years). It has been maintained in isolation with large effective population sizes at the Jocko River State Trout Hatchery.

DeSmet The DeSmet strain was originally introduced into Willow Creek Reservoir, Madison Co., Montana, in 1977, from fish obtained from the Wyoming Department of Fish, Wildlife, and Parks. Several additional plantings of the DeSmet strain have been made into Willow Creek Reservoir subsequent to 1977 . The last planting occurred in 1984. This strain was maintained as a separate breeding stock for at least 14 generations in Wyoming. However, resident and introduced rainbow trout from the Arlee strain, and several strains from the Ennis National Fish Hatchery were present in Willow Creek Reservoir at the time of planting.

Eagle Lake The Eagle Lake strain was derived from resident fish of Eagle Lake, California. Gametes were obtained from this stock in 1980 to establish the strain at the Creston National Fish Hatchery. There have been no known introductions of rainbow trout into Eagle Lake (Busack and Gall, 1980).

Hildebrand Hildebrand was derived from matings between Kamloops and Shasta rainbow trout in 1960. This strain has been maintained in isolation at Mount Lassen Trout Farms for approximately 13 generations since this time.

McConaughy The McConaughy strain was derived from gametes received from rainbow trout reared in Lake McConaughy, Nebraska. Gametes were sent to the Ennis National Fish Hatchery in 1979 and 1980 . The present broodstock is founded from matings between these two year classes and has been maintained with large effective population sizes. Although the number of founders from which gametes were originally obtained is unknown, it is believed to be less than six pairs. Therefore this strain experienced a bottleneck during its inception in Montana. The last planting of hatchery fish tnto the Lake McConaughy parental stock was in 1970 (Van Velson, 1978), approximately 6-7 generations ago.

Shasta The Shasta strain was derived from gametes obtained from the Shasta strain of rainbow trout maintained by the Mt Shasta Fish Hatchery, California. Gametes were sent to the Ennis National Fish Hatchery in 1981 and 1982. The present broodstock is founded from crossing parents derived from these two year classes, and has been maintained with large effective population sizes. The strain in Montana has been selected for growth and egg production. The original gametes were obtained from approximately 100 pair matings in both year classes. This strain was originally established in 1950 and 1951, approximately 14-16 generations ago, by crossing Hot Creek rainbow trout to the Meador strain of rainbow trout from Meador Trout Farm, Pocatello, Idaho (Gall and Gross, 1978; Bussack and Gall, 1980). 
Table 1 Details of the experimental matings between strains of rainbow trout

\begin{tabular}{|c|c|c|c|c|}
\hline Arlee & Jocko River State Trout Hatchery, Arlee, Montana (MT) & 45 & 55 & November, 83 \\
\hline Eagle Lake & Creston National Fish Hatchery, Creston, MT & 25 & 25 & January, 84 \\
\hline Hildebrand & Mt. Lassen Trout Farms, Red Bluff, California & 25 & 25 & August, 83 \\
\hline McConaughy & Ennis National Fish Hatchery, Ennis, MT & 25 & 25 & January, 84 \\
\hline
\end{tabular}

\section{Measurement of developmental rate}

We used hatching time as a measure of developmental rate. Embryos were sampled during hatching and those embryos that had hatched during each interval were counted and removed. Embryos were divided into five or six hatching groups based on their time of hatching relative to other individuals in the cross. For example, the first 17-20 per cent of embryos to hatch in each strain were placed into group 1, the second $17-20$ per cent into group 2 etc. Arlee and Hildebrand were divided into five hatching groups, while DeSmet, Eagle Lake, McConaughy, and Shasta were divided into six groups. Table 2 gives the number of fish in each hatching group and the proportion of the total hatching distribution made up by that group.

Fish from the DeSmet and Hildebrand strains were raised for six months prior to electrophoretic examination, while the Eagle Lake, Shasta, and McConaughy strains were only raised for approximately 2 months or until yolk sac resorption was almost complete because of lack of rearing facilities. For the DeSmet and Hildebrand strains, we sampled 50 and 60 fish, respectively, for elec- trophoresis. In statistical analyses, the DeSmet samples were weighted according to the proportion each group made up of the total observed hatching distribution, as some groups differed by almost 10 per cent in the number of fish sampled. In Eagle Lake, McConaughy, and Shasta, the number of fish sampled from each hatching group was approximately proportional to the size of that hatching group relative to the total hatching distribution (table 2 ).

\section{Electrophoresis}

The following enzymes and loci were investigated: creatine kinase ( $C k 1$; EC 2.7.3.2), glucosephosphate isomerase (Gpi2; EC 5.3.1.9), glycerol-3phosphate dehydrogenase (G3p1; EC 1.1.1.8), glycyl-leucine peptidase (Gl1; EC 3.4.1.1), hexosaminadase (Hex; EC 3.2.1.30), isocitrate dehydrogenase (Idh 2 and $I d h 3,4$; EC 1.1.1.42), lactate dehydrogenase ( $L d h 3$ and $L d h 4 ; \mathrm{EC}$ 1.1.1.27), malate dehydrogenase ( $M d h 3,4$; EC 1.1.1.37), malic enzyme (Me1 and $M e 3$; EC 1.1.1.40), phosphoglucomutase (Pgm2; EC 2.7.5.1), and superoxide dismutase (Sod 1; EC 1.15.1.1). DeSmet is variable for Gpi2, G3p1,

Table 2 Percentage of fish collected representing each hatching group and the number sampled for electrophoresis from each hatching group

\begin{tabular}{|c|c|c|c|c|c|c|c|}
\hline \multirow[b]{2}{*}{ Strain } & & \multicolumn{6}{|c|}{ Hatching group } \\
\hline & & 1 & 2 & 3 & 4 & 5 & 6 \\
\hline \multirow[t]{2}{*}{ Arlee } & $\%$ hatched & $24 \cdot 1$ & $20 \cdot 4$ & $19 \cdot 9$ & $17 \cdot 8$ & $17 \cdot 8$ & - \\
\hline & No. sampled & 50 & 50 & 50 & 50 & 50 & - \\
\hline \multirow{2}{*}{ DeSmet } & $\%$ hatched & $13 \cdot 7$ & $10 \cdot 6$ & $18 \cdot 5$ & $16 \cdot 8$ & $20 \cdot 0$ & $20 \cdot 3$ \\
\hline & No. sampled & 50 & 50 & 50 & 50 & 50 & 50 \\
\hline \multirow[t]{2}{*}{ Eagle Lake } & $\%$ hatched & $4 \cdot 3$ & $20 \cdot 2$ & $39 \cdot 5$ & $12 \cdot 4$ & $11 \cdot 7$ & $11 \cdot 8$ \\
\hline & No. sampled & 23 & 60 & 118 & 37 & 40 & 36 \\
\hline \multirow[t]{2}{*}{ Hildebrand } & $\%$ hatched & $22 \cdot 2$ & $17 \cdot 1$ & $19 \cdot 4$ & $22 \cdot 5$ & $18 \cdot 8$ & - \\
\hline & No. sampled & 60 & 60 & 60 & 60 & 60 & - \\
\hline \multirow[t]{2}{*}{ McConaughy } & $\%$ hatched & $8 \cdot 1$ & $11 \cdot 7$ & $24 \cdot 2$ & $22 \cdot 0$ & $23 \cdot 0$ & $11 \cdot 1$ \\
\hline & No. sampled & 21 & 29 & 80 & 74 & 80 & 35 \\
\hline \multirow[t]{2}{*}{ Shasta } & $\%$ hatched & $10 \cdot 4$ & $17 \cdot 9$ & $12 \cdot 5$ & $17 \cdot 8$ & $14 \cdot 2$ & $27 \cdot 2$ \\
\hline & No. sampled & 35 & 60 & 42 & 59 & 47 & 80 \\
\hline
\end{tabular}


Hex, Idh2, Idh3,4, Mdh3,4, Pgm2, and Sod 1. Eagle Lake is polymorphic at $G 3 p 1, G l 1$, Hex, Idh2, Idh3,4, Mdh3,4, Me3, and Pgm2. Hildebrand is polymorphic at $\operatorname{Idh} 2, \operatorname{Idh} 3,4, \operatorname{Ldh} 3$, $M d h 3,4, P g m 2$, and Sod 1. McConaughy is variable for $C k 1, H e x, I d h 2, I d h 3,4, M d h 3,4$, and $M e 1$. Shasta is polymorphic for $C k 1, G 3 p 1, H e x$, $I d h 2, I d h 3,4, M d h 3,4$, and Pgm2. Hex variation was not examined in Hildebrand as this locus has only recently been investigated in our lab. Sod 1 variation was not examined in Eagle Lake, McConaughy, and Shasta because resolution of the protein products of this locus is poor in embryos. We use the nomenclature recommended by Allendorf and Utter (1979) and Allendorf et al. (1983) in describing these loci. The electrophoretic procedures follow those outlined by Utter et al. (1974), and Allendorf et al. (1977), except that imidazole buffer (Dawson and Mitchell, 1969) was used in the staining solutions for isocitrate dehydrogenase (Idh2), malic enzyme ( $M e 1$ and $M e 3)$, and phosphoglucomutase (Pgm2) to enhance enzyme activity.

\section{RESULTS}

\section{Heterozygosity}

We did not detect a significant association between the number of heterozygous loci per fish in a hatching group and the mean hatching time in days of that group in any strain, except Arlee (Pearson product-moment correlation coefficient; $r=$ $-0.125 ; P<0.05)$. Eagle Lake, Hildebrand, and McConaughy show a negative association between heterozygosity and hatching time $(r=-0.07$; -0.014 ; and -0.086 , respectively). In contrast, DeSmet and Shasta show a positive relationship ( $r=0.018$ and 0.008 , respectively) (fig. 1).

Heterozygotes hatched sooner than homozygotes for 26 out of 43 possible comparisons (table 3). At seven of these loci, $C k 1$ in McConaughy, Gl1 in Eagle Lake, Hex in Arlee and DeSmet, $I d h 3,4$ in DeSmet, $L d h 3$ in Hildebrand, $L d h 4$ in DeSmet, and $M d h 3,4$ in Arlee heterozygotes hatched significantly sooner than homozygotes $(P<$ 0.05; Wilcoxon two-sample test). At five loci, $\mathrm{Hex}$ in Eagle Lake, Idh3,4 in Hildebrand and Shasta, Mdh3,4 in DeSmet, Pgm2 in DeSmet, and Sod 1 in DeSmet, homozygotes hatched significantly sooner than heterozygotes $(P<0.05)$.

Heterozygotes at Ldh4 in both the Arlee and DeSmet strains hatched sooner than homozygotes. In most of the strains examined heterozygotes at
Hex (3 of 5), Mdh3,4 (4 of 6), and Pgm2 (3 of 4) hatched sooner than homozygotes. There are no trends in homozygote versus heterozygote hatching times at $C k 1(1: 1), G 3 p 1(2: 2)$, and $I d h 2$ $(3: 3)$. Homozygotes tended to hatch sooner than heterozygotes at $I d h 3,4$ (4 of 6) and $\operatorname{Sod} 1$ (2 of 3) (table 3).

We determined which loci are significantly associated with differences in hatching time between homozygotes and heterozygotes among strains by using a combined probabilities test (Sokal and Rohlf, 1981). This tests for significant differences in the hatching distributions between homozygotes and heterozygotes regardless of the direction of this association. The natural logarithms of the probabilities from each independent test of significance for each strain were summed to obtain a single test statistic for each locus. There are significant differences at $\operatorname{Hex}(P<0.01)$, Idh3,4 $(P<0.001)$, Ldh4 $(P<0.01), M d h 3,4(P<$ $0.05)$, and Sod $1 \quad(P<0.025)$. There are no significant differences at $C k 1(P>0 \cdot 1), G 3 p 1(P>$ $0.5)$, Idh2 $(P>0.5)$, and Pgm2 $(P>0.05)$.

\section{Alleles at individual loci}

For each strain, we compared the mean hatching time of the most common homozygous genotype $(100 / 100)$ at each locus in rainbow trout and the alternate homozygous genotype. Duplicated loci (Idh 3,4 and $M d h 3,4)$ were not examined as all fish have at least one copy of the most common allele. There are no significant differences between the mean hatching times of common homozygous genotypes versus alternate homozygous genotypes. Common homozygous genotypes hatched sooner in 9 out of 16 possible cases.

At loci where more than one comparison was possible (Hex, Idh2, and Sod 1 ), no consistent trend was observed. The common homozygotes hatched sooner than the alternate homozygotes in two out of the four strains at Hex, two out of five strains at $I d h 2$, and two out of three strains at Sod 1 (table 3). Although Sodl (30/30) homozygotes hatched sooner than the common homozygotes in the Hildebrand strain, the common homozygotes hatched sooner than both alternate homozygous classes $(152 / 152+30 / 30)$ when these two genotypes are averaged together.

We compared the hatching distributions of fish with one of the three variant alleles at $I d h 3,4$, to those with the other variant alleles. Three comparisons are possible: fish with (114) vs. (71) alleles, fish with (114) vs. (40) alleles, and fish with (71) vs. (40) alleles. There are no consistent 

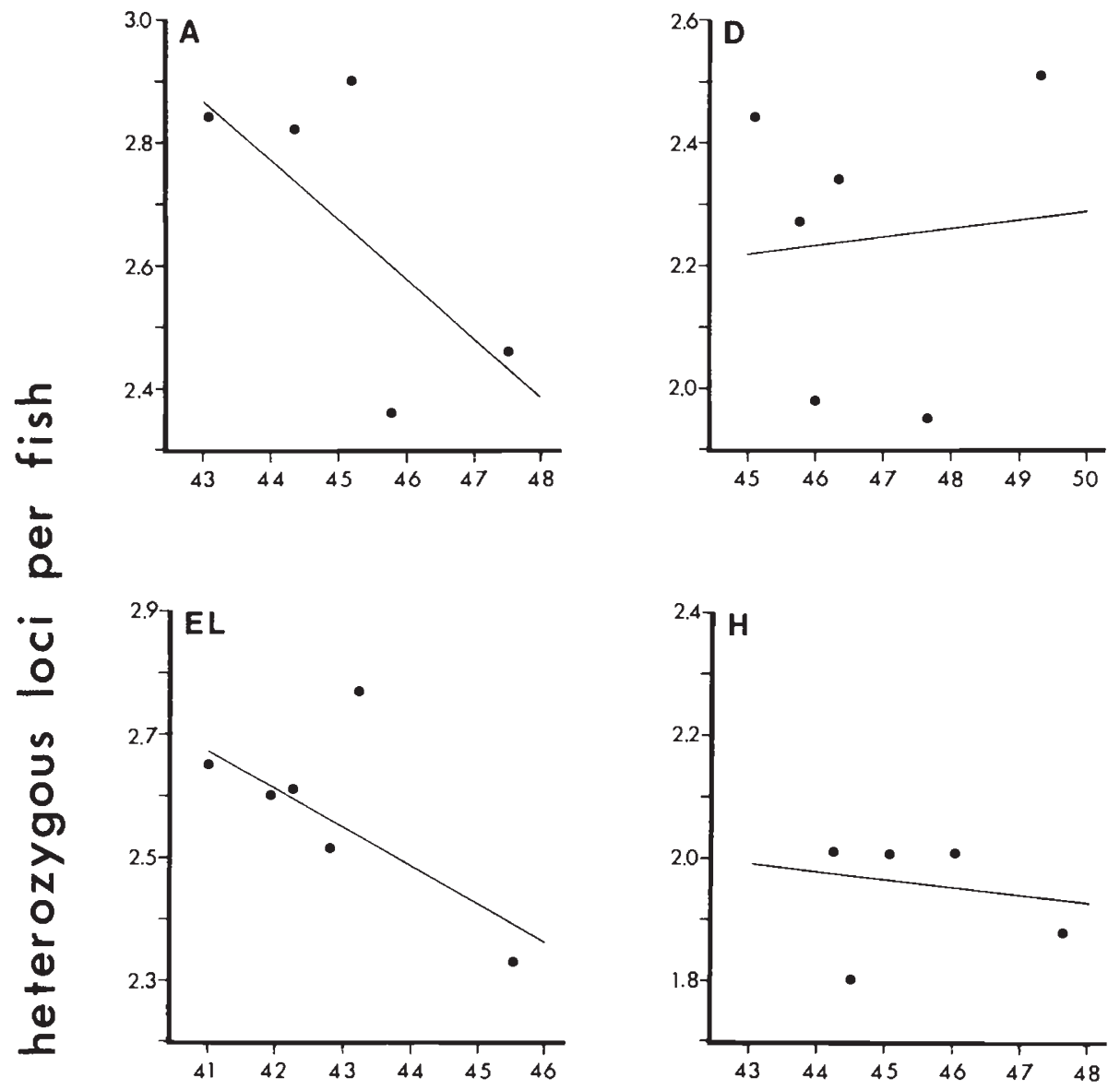

$\overleftarrow{0}$
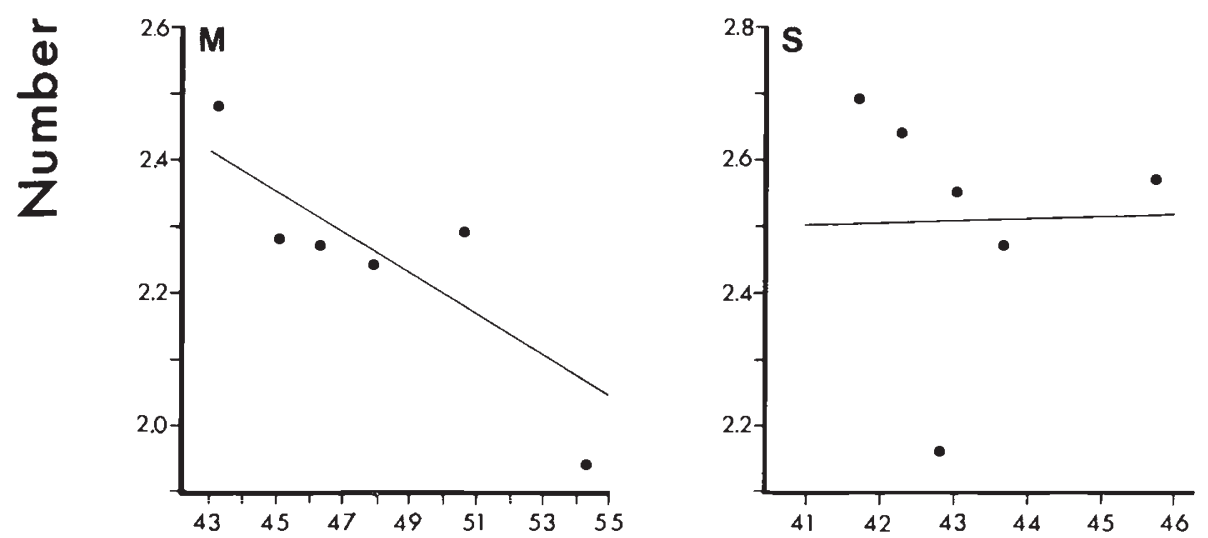

\section{Day of development}

Fig. 1 Correlation between number of heterozygous loci per fish and mean hatching time of its group for six strains of rainbow trout. Points are the average heterozygosities of all fish within a hatching group. The line is the principal axis of the correlation ( $\mathrm{A}=$ Arlee, $r=-0.125 ; \mathrm{D}=$ DeSmet, $r=0.018 ; \mathrm{EL}=$ Eagle Lake, $r=-0.07 ; \mathrm{H}=$ Hildebrand, $r=-0.014 ; \mathrm{M}=$ McConaughy, $r=-0.086 ; \mathrm{S}=$ Shasta, $r=0.008$ ). 
Table 3 Mean hatching time* in days of fish with different genotypes at 14 polymorphic loci examined in six strains of rainbow trout $(\mathrm{A}=$ Arlee; $\mathrm{D}=\mathrm{DeSmet} ; \mathrm{EL}=$ Eagle Lake; $\mathrm{H}=$ Hildebrand; $\mathrm{M}=\mathrm{McC}$ Conaughy; $\mathrm{S}=$ Shasta $)$

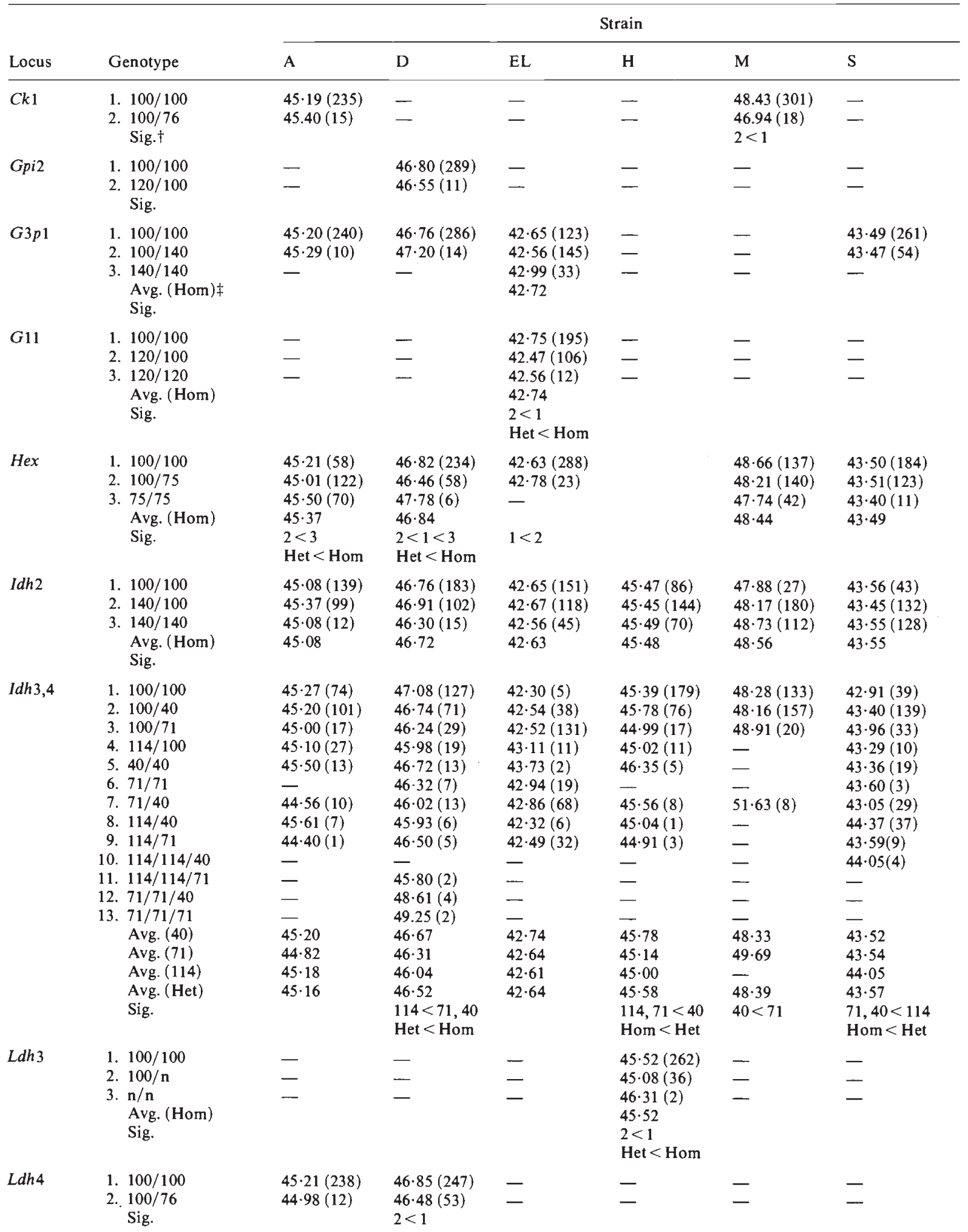


Table 3 (cont.)

\begin{tabular}{|c|c|c|c|c|c|c|c|}
\hline \multirow[b]{2}{*}{ Locus } & \multirow[b]{2}{*}{ Genotype } & \multicolumn{6}{|c|}{ Strain } \\
\hline & & A & D & EL & H & $\mathrm{M}$ & $S$ \\
\hline$M d h 3,4$ & $\begin{array}{l}\text { 1. } 100 / 100 \\
\text { 2. } 100 / 83 \\
\text { 3. } 83 / 83 \\
\text { 4. } 100 / 74 \\
\text { 5. } 125 / 100 \\
\text { 6. } 125 / 83 \\
\text { 7. } 83 / 83 / 83 \\
\text { Avg. }(83) \\
\text { Avg. (125) } \\
\text { Avg. (Het) } \\
\text { Sig. }\end{array}$ & $\begin{array}{l}45 \cdot 39(121) \\
45 \cdot 06(113) \\
44 \cdot 67(16) \\
- \\
- \\
- \\
\\
45 \cdot 01 \\
\text { Het }<\text { Hom }\end{array}$ & $\begin{array}{l}46 \cdot 69(250) \\
47 \cdot 07(33) \\
- \\
47 \cdot 49(17) \\
- \\
- \\
- \\
47 \cdot 21 \\
83<74 \\
\text { Hom }<\text { Het }\end{array}$ & $\begin{array}{l}42 \cdot 65(254) \\
42 \cdot 63(60) \\
- \\
- \\
- \\
-\end{array}$ & $\begin{array}{l}45 \cdot 51(207) \\
45 \cdot 40(87) \\
44 \cdot 83(6) \\
- \\
- \\
-\end{array}$ & $\begin{array}{l}48 \cdot 40(161) \\
48 \cdot 44(119) \\
47 \cdot 52(29) \\
- \\
47 \cdot 36(3) \\
49 \cdot 30(7) \\
- \\
48 \cdot 31 \\
48 \cdot 72 \\
48 \cdot 29\end{array}$ & $\begin{array}{l}43 \cdot 48(126) \\
43 \cdot 44(153) \\
43 \cdot 61(39) \\
- \\
- \\
\overline{44 \cdot 05(5)}\end{array}$ \\
\hline$M e 1$ & $\begin{array}{l}\text { 1. } 100 / 100 \\
\text { 2. } 100 / 55 \\
\text { Sig. }\end{array}$ & - & - & - & - & $\begin{array}{l}48 \cdot 42(280) \\
47 \cdot 93(35)\end{array}$ & - \\
\hline$M e 3$ & $\begin{array}{l}\text { 1. } 100 / 100 \\
\text { 2. } 100 / 75 \\
\text { Sig. }\end{array}$ & - & - & $\begin{array}{l}42 \cdot 68(272) \\
42 \cdot 44(40)\end{array}$ & - & - & - \\
\hline $\operatorname{Pgm} 2$ & $\begin{array}{l}\text { 1. } 100 / 100 \\
\text { 2. } 100 / 90 \\
\text { 3. } 90 / 90 \\
\text { Avg. (Hom) } \\
\text { Sig. }\end{array}$ & $\begin{array}{l}45 \cdot 22(234) \\
44 \cdot 86(16) \\
-\end{array}$ & $\begin{array}{l}46 \cdot 64(200) \\
47 \cdot 03(91) \\
47 \cdot 55(9) \\
46 \cdot 68 \\
1<2,3 \\
\text { Hom }<\text { Het }\end{array}$ & $\begin{array}{l}- \\
-\end{array}$ & $\begin{array}{l}45 \cdot 47(256) \\
45 \cdot 43(44) \\
-\end{array}$ & $\begin{array}{l}- \\
-\end{array}$ & $\begin{array}{l}43 \cdot 50(308) \\
43 \cdot 24(15) \\
-\end{array}$ \\
\hline Sod 1 & $\begin{array}{l}\text { 1. } 100 / 100 \\
\text { 2. } 152 / 100 \\
\text { 3. } 100 / 30 \\
\text { 4. } 152 / 152 \\
\text { 5. } 30 / 30 \\
\text { Avg. (Hom) } \\
\text { Avg. (Het) } \\
\text { Sig. }\end{array}$ & $\begin{array}{l}45 \cdot 24(132) \\
45 \cdot 09(94) \\
- \\
45 \cdot 39(24) \\
- \\
45 \cdot 26\end{array}$ & $\begin{array}{l}46 \cdot 62(171) \\
47 \cdot 01(117) \\
\overline{46} \\
\overline{46} \cdot 99(12) \\
1<2,4 \\
\text { Hom }<\text { Het }\end{array}$ & & $\begin{array}{l}45 \cdot 43(122) \\
45 \cdot 46(126) \\
45 \cdot 92(17) \\
45 \cdot 51(31) \\
44 \cdot 66(4) \\
45 \cdot 43 \\
45 \cdot 51\end{array}$ & & \\
\hline $\begin{array}{l}\# \text { of } 100 \\
\# \text { of } 100\end{array}$ & $\begin{array}{l}\text { t }<\text { Hom } \S \\
\text { om }<\text { Het }\end{array}$ & $\begin{array}{l}6 \\
3\end{array}$ & $\begin{array}{l}4 \\
5\end{array}$ & $\begin{array}{l}4 \\
3\end{array}$ & $\begin{array}{l}4 \\
2\end{array}$ & $\begin{array}{l}5 \\
1\end{array}$ & $\begin{array}{l}3 \\
3\end{array}$ \\
\hline
\end{tabular}

* The numbers in parentheses indicate the number of fish sampled with the designated genotype.

$\uparrow$ Indicates significant differences between the numbered genotypes. All pairwise genotypic comparisons are non-significant unless indicated. Genotypes which hatched significantly earlier than other genotypes are indicated as taking less time ( $<$ ) to hatch. If more than one homozygous or heterozygous genotype is compared then these genotypes are combined, and significant differences between these combined classes are indicated on the line below.

$\ddagger$ Indicates the average hatching time in days of combined homozygous (Hom) or heterozygous (Het) genotypes.

$\S$ Indicates the number of loci at which heterozygotes hatched sooner than homozygotes, and the number of loci at which homozygotes hatched sooner than heterozygotes

differences between the hatching distributions of fish with these allelic types among strains. In DeSmet and Hildebrand, fish with the (114) allele hatched significantly sooner than fish without this allele, while in Shasta, fish with this allele hatched significantly later. In Hildebrand, fish with the (71) allele hatched significantly sooner than fish with the (40) allele, while the reverse occurred in McConaughy. In the single comparison possible at $M d h 3,4$, fish with the (83) allele hatched significantly sooner than fish with the (74) allele in the DeSmet strain.

\section{DISCUSSION}

\section{Enzyme variation and developmental rate}

The results of this study suggest that heterozygotes tend to develop faster than homozygotes. 
Heterozygotes developed faster than homozygotes at 26 out of 43 comparisons. Heterozygotes hatched sooner than homozygotes at the majority of loci examined in Arlee, Eagle Lake, Hildebrand, and McConaughy. In Shasta and DeSmet, homozygotes hatched sooner than heterozygotes at eight out of the fifteen loci examined.

However, significant positive associations between heterozygosity and hatching time at loci in some strains and significant negative associations at these loci in other strains suggest that these enzyme loci are marking chromosomal segments that carry genes that affect developmental rate. For example, heterozygotes at $I d h 3,4$ hatched significantly earlier than homozygotes in DeSmet but significantly later in Hildebrand and Shasta. Significant negative and positive associations between heterozygosity and hatching time were also detected at Hex, Mdh3,4, and Sod 1. At other loci, such as $I d h 2$ and $G 3 p 1$, no significant associations were observed in several strains. The direction of association between heterozygosity and developmental rate is dependent upon the frequency with which heterozygotes at the enzyme loci are associated with other genes that accelerate or delay development. Therefore, the direct association between heterozygosity and developmental rate at the loci examined in this study is weak. Rather, these loci appear to mark chromosomal segments carrying other genes that influence developmental rate.

These data support our hypothesis (Danzmann et al., 1986) that differences in developmental rate between homozygotes and heterozygotes may account for the positive association between developmental stability and heterozygosity reported by Leary et al. $(1983 ; 1984)$. We have observed that the magnitude of association between heterozygosity and hatching time differs between strains of rainbow trout and enzyme loci. In many cases, those strains and loci that showed significant associations between heterozygosity and developmental rate also showed associations between heterozygosity and developmental stability (Leary et al., 1983, 1984). For example, there is a significant negative correlation between developmental time and heterozygosity in the Arlee strain (Danzmann et al., 1986). This strain also showed a significant positive association between heterozygosity and developmental stability in two separate generations (Leary et al., 1984). McConaughy and Shasta were also examined in both studies and showed a nonsignificant association between heterozygosity and both developmental rate and stability.
Leary et al. (1983; 1984) have identified significant association between heterozygosity at $G l 1$, $I d h 3,4, L d h 5, M e 4, P g m 2$, and Sod 1 and developmental stability. Four of these six loci ( $G l 1, \operatorname{Idh} 3,4$, $P g m 2$, and Sod 1) are significantly associated with developmental rate in this study. We did not examine $L d h 5$ and $M e 4$. These authors also indicate that $M d h 3,4$ and $\operatorname{Sod} 1$ had the strongest positive relationship between developmental stability and heterozygosity. Significant differences in the hatching time of homozygotes and heterozygotes at $M d h 3,4$ were observed in the present study. Heterozygotes tended to hatch earlier than homozygotes in four of the six strains examined. However, in two of the three strains examined for Sod 1 in the present study, homozygotes hatched sooner than heterozygotes. These two strains, DeSmet and Hildebrand, were not examined by Leary et al. (1984).

The three positive and three negative significant differences between heterozygosity and hatching time in the DeSmet strain warrants some discussion. As mentioned in materials and methods this strain has been interbreeding with resident rainbow trout in Willow Creek Reservoir since its introduction in 1977. Large gametic phase disequilibrium effects are likely to exist in this strain. Genes influencing developmental rate would be associated with different alleles contributed by each parental stock. The other strains examined in this study have been randomly mating for a larger number of generations without introductions from other stocks. Consequently, in these strains, genes influencing developmental rate are expected to be randomly associated with variant alleles at enzyme loci, except for tightly linked chromosomal segments.

\section{Mechanism of action}

If the genes affecting developmental rate act additively then heterozygotes at linked enzyme loci would have intermediate hatching times to alternate homozygotes. However, heterozygotes at enzyme loci may be equivalent to one of the homozygous classes if the genes affecting developmental rate act dominantly. Enzyme heterozygotes would be outside the range of the homozygotes only if there are overdominant genes affecting developmental rate.

We tested these alternatives with enzyme loci having significant differences in developmental time between homozygotes and heterozygotes. Five such comparisons are possible at four loci in three of the strains studied. At four of these five loci, 
Gl1 in Eagle Lake, Hex in Arlee, Pgm 2 in DeSmet, and Sod 1 in DeSmet, there are no significant differences in the developmental rate of heterozygotes and one homozygous genotype, suggesting an association with dominant alleles that accelerate or retard developmental rate. Heterozygotes at Hex in Arlee and Gll in Eagle Lake hatched significantly sooner than one homozygous genotype, while heterozygotes at Pgm2 and $\operatorname{Sod} 1$ in DeSmet hatched significantly later than one homozygous genotype. Only at Hex in DeSmet are there significant differences in the hatching distributions of all three genotypes. Heterozygotes hatched significantly sooner than either homozygous genotype, indicating overdominance. These results suggest the presence of non-additively acting genes affecting developmental rate in rainbow trout.

Acknowledgements We thank Jack Boyce, Jack Call, Jim Crepeau, Daryl Jennings, Phil Mackey, Wes Orr, Larry Peterson, and Dick Vincent for providing the rainbow trout gametes, and Ralph Garbugt, George Holton, Phil Mackey, and Wes Orr for providing information on the history of the strains. Kathy Knudsen and Rebecca Everett assisted with the experimental matings. This study was supported by NSF grant BSR8300039 awarded to FWA. MMF was supported by a postgraduate scholarship from NSERC (Canada).

\section{REFERENCES}

ALLENDORF, F. W., KNUDSEN, K. L. AND LEARY, R. F. 1983. Adaptive significance of differences in the tissue-specific expression of a phos phoglucomutase gene in rainbow trout. Proc. Natl. Acad. Sci. USA, 80, 1397-1400.

ALLENDORF, F. W., MITCHELL, N., RYMAN, N. AND STÅHL, G. 1977. Isozyme loci in brown trout (Salmo trutta L.): detection and interpretation from population data. Hereditas, 86, 179-190.
ALLENDORF, F. W. AND UTTER, F. M. 1979. Population genetics of fish. In Hoar, W. S., Randall, D. J. and Brett, J. R. (eds) Fish Physiology, vol. 8, Academic Press, New York, p. 407-454.

BOULEKBACHE, H. 1981. Energy metabolism in fish development. Amer. Zool., 21, 377-389.

BUSACK, C. A. AND GALL, G. A. E. 1980. Ancestry of artificially propagated California rainbow trout strains. Calif. Fish and Game, 66, 17-24.

DANZMANN, R. G., FERGUSON, M. M., ALLENDORF, F. W. AND KNUDSEN, K. L. (1986). Heterozygosity and developmental rate in a strain of rainbow trout (Salmo gairdneri). Evolution 40, 86-93.

DAWSON, D. M. AND MITCHELL, R. 1969. The isoenzymes of phosphoglucomutase. Biochemistry, 8, 609-614.

DiMICHELE, L. AND POWERS, D. A. 1982. LDH-B genotype specific hatching times of Fundulus heteroclitus embryos. Nature, 196, 563-564.

DiMrCHELE, L. AND POWERS, D. A. 1984. Developmental and oxygen consumption rate differences between lactate dehydrogenase-B genotypes of Fundulus heteroclitus and their effect on hatching time. Physiol. Zool., 57, 52-56.

GALL, G. A. E. AND GROSS, S. J. 1978. A genetic analysis of the performance of three rainbow trout broodstocks. Aquaculture, $15,113-127$

LEARY, R. F., ALLENDORF, F. W. AND KNUDSEN, K. L. 1983 Developmental stability and enzyme heterozygosity in rainbow trout. Nature, 301, 71-72.

LEARY, R. F., ALLENDORF, F. W. AND KNUDSEN, K. L. 1984 Superior developmental stability of heterozygotes at enzyme loci in salmonid fishes. Amer. Natur., 124, 540-551.

LERNER, I. M. 1954. Genetic homeostasis. Dover Publications, New York.

SOKAL, R. R. AND ROHLF, J. F. 1981. Biometry, Second Edition. W. H. Freeman and Co., San Francisco.

UTTER, F. M., HODGINS, H. O. AIND ALLENDORF, F. W. 1974. Biochemical genetic study of fishes: potentialities and limitations, In Malins, D. C. and Sargent, J. R. (eds) Biochemical and biophysical perpsecitves in marine biology, Vol. 1, pgs. 213-238. Academic Press, New York.

VAN VELSON, R. C. 1978. The McConaughy rainbow: Life history and a management plan for the North Platte river valley. Nebraska Tech. Ser., 2, Nebraska Game and Parks Comm. 